\title{
Servant Leadership: A Phenomenological Study Of Practices, Experiences, Organizational Effectiveness, And Barriers
}

Amy R. Savage-Austin, PhD, Shorter University, USA Andrew Honeycutt, DBA, Shorter University, USA

\begin{abstract}
The subject of leadership is complex, and one of the main issues facing organizational leaders today is how to motivate employees to actively participate in the efforts that lead to accomplishing organizational goals. This study gathered lived experiences of 15 organizational leaders who practice the servant leadership philosophy, and explored how business leaders link their servant leadership practices to their organization's effectiveness. The qualitative responses obtained during this study indicated that the perceived organizational barriers that prevent the servant leadership practices are the organization's culture, the fear of change, and the lack of knowledge regarding the servant leadership philosophy. This study also gained insight into the impact that these organizational barriers have on one's ability to practice servant leadership.
\end{abstract}

Keywords: Servant Leader, Leadership, Organizational Effectiveness, Barriers

\section{PURPOSE OF THE STUDY}

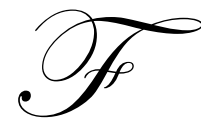

or years scholars have tried to ascertain the true characteristics, styles, attributes, and the like that explain the phenomenon of leadership. Literature suggests that historically leadership theory and the empirical supporting research have been regarded as a fractured and confusing set of contradictory findings, at times making assertions without coherence or interpretability (Chemers, 2000). The subject of leadership is complex, and one of the main issues facing organizational leaders today is how to motivate and how to gain buyin so that employees actively participate in the efforts that lead to accomplishing organizational goals. According to Lynham and Chermack (2006), leadership is a phenomenon that results in the need to pursue desired outcomes by desired stakeholders within an organization.

Several existing theories and models (e.g., transformational, transactional, charismatic, authentic, and others) sufficiently support the rationale for the way leaders approach the task of leading (Northouse, 2004). Comparatively, most leadership theories and leadership models highlight the leader's role in getting followers to serve and support the organization willingly and participate actively in goal attainment activities. Yet none of these models illuminate the need for leaders to serve the followers. Nor do these theories and models address how leadership should work collectively with followers to achieve desired organizational results. The servant leadership philosophy addresses both the leader's and the followers' roles, suggesting that meeting the needs of followers and encouraging the input of followers in the decision-making process will allow leaders to overcome the challenges faced by modern organizations. As such, the philosophy of servant leadership provides a different way of understanding the responsibility of leadership, and the servant leader assumes an attitude of service, acting as a steward over his or her area of responsibility (Greenleaf, 1977).

Organizations benefit from understanding how leadership engages followers in day-to-day activities because the outcome of this act contributes to the organization's ability to be effective. But organizations must be willing to solicit constructive feedback from organizational members to assess the effectiveness of leadership practices and the impact of leadership approaches. A way that researchers can ascertain the level of servant 
leadership that is being practiced is by polling organizational members and gaining feedback. Servant-led organizations are identified through internal and external assessments; an organization's level of servant leadership practices are based upon the leader's demonstration of servant leadership characteristics. According to Spears (2004), the top three characteristics used to measure a leader's level of servant leadership practice are listening, empathy, and healing.

Understanding the tools needed for effective leadership is important, and the servant leadership philosophy offers leaders the opportunity to not only understand the needs of the organization but also allows for the leaders to incorporate one of the most valuable tools necessary in making the organization effective: followers. Spears (2004) asserted that servant leadership has made an impact on leaders and managers, causing leaders to raise their standard practices toward developing and utilizing servant leadership characteristics.

\section{STUDY RELEVANCE}

In the $21^{\text {st }}$ Century business environment, companies have found it necessary to transform from a business that simply earns a profit to a business that looks for ways to maintain a competitive advantage. Leaders are now not only tasked with strategizing to come up with profit-earning activities, but leaders are also tasked with strategizing to motivate and engage employees to give more back to the organization in order to achieve desired results (i.e., increased productivity, increased earnings, and so forth). Unfortunately, Klenke (2003) noted that productivity within the U.S. corporations has declined due to the use of strategic management decisions resulting in outsourcing, corporate mergers, and acquisitions and downsizing, as well as leadership misconduct. This assertion indicates that leadership's decision-making tools have negatively affected the work environment, creating a culture where organizational members are left with a void and displacement. Although past business practices have dictated that the focus of an organization is to realize a profit, researchers continue to assert the need for organizations to embrace models that emphasize a people-centered approach to management and leadership. Servant leadership is one such approach.

Literature suggests that the servant leader is distinguishable through the care that is taken to ensure that other people's highest priority needs are being served (Greenleaf et al., 2002). For example, instead of followers serving the needs of the leader, the leader ensures that the needs of the subordinates are met. Through training and skill building, empowered followers are developed and encouraged to creatively solve problems. The goal of the servant leader is to strengthen others and to encourage a collective approach to fulfilling organizational objectives.

The philosophy of servant leadership is often compared to two other approaches to leadership: the transformational approach and the authentic approach. An excerpt derived from work by Avolio and Gardner (2005) helps researchers understand the attributes of the two approaches to leadership. For example, characteristics noted between the authentic and transformational leadership models and the servant leadership philosophy are as follows: integrity, trust, respect, and authenticity. Interestingly, the transformational approach emphasizes the ethical responsibility of the leader and calls attention to the need for leaders to communicate vision morally and ethically. The authentic leader is noted as having the ability to provide an unbiased comprehension of multiple points of view (or sides) of an issue while behaving in accordance with one's true self (Avolio \& Gardner). Research also indicates that the common theme of the servant leader revolves more around the well-being of others. The two leadership models are referenced throughout the discussion in order to show how the leadership attributes compare and contrast to the attributes that contribute to the servant leadership philosophy.

There are world-class organizations that have been identified as utilizing the principles and concepts outlined in the servant leadership philosophy. Branch (1999) asserted that companies such as Southwest Airlines, Starbucks, Steak-n-Shake, Synovus, and TD Industries have modeled their management practices around the servant leadership concepts and are considered as top places to work in America. Chick-fil-A also attested that its success is largely due to the manifestation of principles and characteristics of servant leadership practices (Conley et al., 2004). With these types of companies as examples, researchers have a basis for contending that the servant leadership philosophy is gaining validation (Washington, 2007). 
As is the case with for-profit companies, profitability and the various factors of the business that affect the bottom line are of most concern; these factors usually gain the most attention. Additionally, with today's increased competition and technological advancements, businesses have become more focused on creating a lean environment through process automation and less focused on appreciating the individual and their contribution to accomplishing the organizational goal of earning a profit.

Organizations have experienced significant changes since the new millennium, and it is expected that the realm of leadership has also transitioned to meet the changing needs of business. Literature supports the idea that leadership styles that once worked may no longer be applicable in this new era, as for-profit companies are investing large amounts of money in "pursuit of the recipe for leadership success" (Lynham \& Chermack, 2006, p. 73). The servant leadership philosophy allows for a fresh way of approaching the task of leadership, dispelling the traditional top-down approach to leadership that excluded followers from the decision-making process. Through stewardship and service, servant leaders are able to shift the paradigm of leadership (Greenleaf, 1977).

For-profit organizations benefit from understanding the possible barriers that prevent servant leadership practices; leadership that engages followers in day-to-day activities can dramatically affect the organization's ability to be effective. While much has been written about servant leadership, instruments used to measure servant leadership characteristics, and the practice of servant leadership, a review of literature revealed that little has been written about understanding the impact that identified barriers have on an organizational leader's ability to practice the philosophy of servant leadership. Previous studies indicated that understanding the impact that identified organizational barriers have on servant leadership practices would help leaders develop strategies to overcome these impediments and add to the body of existing knowledge.

Review of the literature indicated that some leadership researchers recognize the importance of a leader incorporating the right leadership model that will allow for organizations to achieve desired results. Blanchard and Hodges (2003) asserted that a prerequisite for survival in today's organization is that leaders know the principles under which they operate. Additionally, understanding how to measure the success of a given leadership approach is critical; Sheep (2004) concluded that being able to answer the question of how to measure a system that meets the needs of the contemporary work situation is necessary to achieve organizational effectiveness.

The literature noted that several variables contribute to the effectiveness of an organization (i.e., approaches to leadership, followership, and organizational culture). It is the same with the effectiveness of servant leadership. An organizational structure with elements (barriers) the do not support servant leadership principles will impede the efforts of servant-oriented leaders. Kupers (1998) supported this assertion and concluded that responsive servant leadership requires organizational changes concerning basic assumptions and structures.

This study on the impact of organizational elements (barriers) to servant leadership practices may allow servant leaders in the for-profit work environment to be better equipped to handle the challenges faced within the modern-day organization. The realm of leadership has shifted over the years, and the evolution of business requires a broader perspective when analyzing which model best fits a given work environment. Servant leadership requires a partnership between leaders and followers. In the end, the recipe for a leader's success includes being able to connect with followers where they are now, being able to affirm their worth, and being able to build from there (Hultman, 2006).

\section{STUDY BACKGROUND AND METHODOLOGY}

This study also revealed the perceived organizational barriers (beliefs, symbols, norms, values, rules) that prevent the servant leadership practices, and gained insight into what impact these perceived barriers have on the leaders' ability to practice servant leadership within their work environments. Studies previously performed by other researchers examined the practice of servant leadership within not-for-profit work environments (e.g., educational, service industry, and the like). Few studies address the practice of servant leadership within the forprofit work environment. Some studies that have previously been conducted include research that examined the practice of servant leadership in public education, servant leadership practices within the church, and the impact of servant leadership practices on congregational donations within the church. 
Foster (2000) completed a phenomenological study that identified organizational elements (barriers) that impede the practice of servant leadership. In this study, 10 leaders were interviewed to gain their perspectives on what they perceived as organizational barriers that impeded their ability to practice servant leadership. These managers identified things such as the "command-and-control leadership style, a non-trusting work environment, a paternalistic culture, and a lack of empowerment" (Foster, pp. 335-336) as elements that prevent effective practice of servant leadership. Foster concluded that although barriers do exist, there are solutions that, with effort, in organizations where servant leadership practices are being impeded, management would be able to conquer such elements. Servant leadership practices would prevail in an environment that fosters trust and inclusion, and dispels the command-and-control leadership style.

\section{STUDY METHODOLOGY}

The methodology of this phenomenological study was to gather and explore the lived experiences of 15 business leaders who practice the servant leadership philosophy, and examined how these business leaders link their servant leadership practices to effectiveness within their business environments. These experiences provided a new level of insight regarding the impact that organizational elements (barriers) have on the leaders' ability to practice servant leadership. The research questions that framed this study were as follows:

1. What are the servant leadership practices and experiences of business leaders within their organizations?

2. How do business leaders link their servant leadership practices to organizational effectiveness within their organizations?

3. What do business leaders perceive as organizational elements (barriers) that prevent servant leadership practices, and what impact do these perceived elements have on the leaders' ability to practice servant leadership?

A phenomenological qualitative study was conducted to understand the experiences, impediments, and links to organizational outcomes of business executives who practice servant leadership. Phenomenology is said to be a "philosophical approach to analyzing the phenomena that are part of man's awareness (Arbnor \& Bjerke, 1997, p. 38). The servant leadership philosophy can be viewed as a social practice, and a methodology used to study social practices is phenomenology.

The phenomenological approach to this research study used a qualitative interview. The purpose of the qualitative interview is to gain information regarding a particular research topic, and the technique used to facilitate answers to these questions is usually some type of questionnaire.

\section{CONCLUSION} conclusions:

The experiences and practices of the servant leaders interviewed for this study support the following

\section{Conclusion 1}

Literature and the findings of this study supported the assertion that the ultimate test of a leader's effectiveness is based upon how a leader is allowed to demonstrate his or her traits and character. Servant leaders demonstrate their traits and character through interaction with followers and other leaders within the organization; the traits and characteristics of servant leaders include their commitment to growth of people, stewardship, and building community. Servant leadership practices have been noted to provide leaders with the opportunity to experience change and to invite followers to change. Results of this study were consistent with what has already been purported by other researchers (Foster, 2000); organizations that embrace servant leadership practices build a sense of community within the organization and foster an environment where followers are allowed to flourish and grow.

The practice of servant leadership profoundly affects the nature of an organization. Research showed that something as simple as openly communicating with others allows for the creation of trust, the exchange of 
information, and increased loyalty between leaders and organizational members. Additional benefits to adopting the philosophy of servant leadership include improvement in the decision-making process, increase in productivity, improvement in morale, and reduction in employee turnover. It is surprising that more organizations have not seen the need to provide better support for their leaders to practice the servant leadership philosophy.

\section{Conclusion 2}

While literature supported the argument that the practice of servant leadership delivers several benefits, findings of this study revealed that leaders who practice servant leadership still experience difficulty with convincing others of the viability and effectiveness of the servant leadership philosophy. Unfortunately, when organizations do not support the practice of the servant leadership philosophy, neither servant leaders nor followers are able to reach their fullest potential. Additionally, organizations that do not support servant leaders also miss out on the benefits that could otherwise be realized from servant leadership practices.

This study's results coincided with previous research, and concluded that the most common barriers to servant leadership practices are the organization's culture, the fear of change due to lack of presence of other servant leaders within the organization, and the lack of knowledge regarding the philosophy of servant leadership practices. Additional barriers that prevent leaders from practicing the servant leadership philosophy include lack of confidence in the effectiveness of the servant leadership philosophy, time, and paradigms regarding the type of business setting that best supports servant leadership practices (e.g., nonprofit vs. for-profit organizations).

\section{Conclusion 3}

The barriers that prevent the practice of the servant leadership philosophy negatively impact organizations. Findings from this study showed that servant leaders who work in environments that do not support servant leadership practices miss the opportunity to fully develop and teach their followers. Findings also supported the conclusion that organizational elements (barriers) make it difficult for servant leaders to interact with others outside of their inner circle, and perpetuate the development of silos; the impact of silos within an organization can be devastating. Leaders who develop and work within silos become so focused on accomplishing the goals of their small piece of the organization that they lose sight of the bigger picture. These leaders begin to hoard information, and cease to seek out opportunities that lead to knowledge sharing and cross-training. Ultimately, followers miss the opportunity to expand upon their current knowledge base and to develop in the areas necessary for other positions within the organization.

Servant leaders thrive on the opportunity to share ideas because the process of sharing creates accountability for the results that are generated from their actions. However, organizational barriers minimize collaboration that would otherwise occur between servant leaders and followers, resulting in minimal inclusion of followers in the decision-making process. It is important to note that in times such as these (when the economy dictates that leaders make difficult decisions in order to keep their organizations afloat), followers expect leaders to act in the best interest of not only the company but also in the best interest of the followers. Thus, it is important to include followers in the decision-making process. Not including followers in the decision-making process results in the followers' loss of confidence in leadership, and ultimately their loss of faith in the organization's ability to withstand the storm created by the economy. The overall impact results in the followers' desire to leave the organization due to the feeling of instability and insecurity.

\section{AUTHOR INFORMATION}

Dr. Amy Savage-Austin is the Director of Undergraduate Programs and an Assistant Professor of Management at Shorter University. Prior to serving as full time faculty at Shorter University, Dr. Savage-Austin worked for companies such as The New York Times Co., Northrop Grumman, and The Home Depot, USA. She earned her BS Degree from Hampton University and her MBA from Philadelphia University. She completed her PhD in Organizational Management with specialization in Leadership from Capella University. Amy peer reviews for the American Psychological Association, is a member of The Greenleaf Center for Servant Leadership, and The National Association of Female Executives. 
Dr. Andrew E. Honeycutt, Distinguished Fellow, Shorter University, is the recipient of the Doctor of Business Administration degree in Marketing from Harvard University and the Masters in Business Administration degree from Boston University. He is also a Northwestern University Nissan Marketing Fellow. His much utilized business expertise is evidenced by his service on advisory boards and board of directors to businesses, banks, community organizations, foundations and state governments.

\section{REFERENCES}

1. $\quad$ Abshire, D. (2007). Trustworthy leaders. Leadership Excellence, 24(4), 20.

2. Avolio, B. J., \& Gardner, W. L. (2005). Authentic leadership development: Getting to the root of positive forms of leadership. The Leadership Quarterly, 16, 315-338.

3. $\quad$ Bennis, W. G. (2006). The Drucker legacy. Leadership Excellence, 23(1), 15-16.

4. Bennis, W. G., \& Biederman, F. W. (1997). Organizing genius: The secrets of creative collaboration. Reading, MA: Addison-Wesley.

5. Branch, S. (1999, January). The 100 best companies to work for in America. Fortune, 139, 118.

6. Bromley, H., \& Kirschner-Bromley, V. (2007). Are you a transformational leader? Physician Executive, 33(6), 54-57.

7. Chemers, M. M. (2000, March). Leadership research and theory: A functional integration. Group Dynamics: Theory Research and Practice, 4(1), 27-43.

8. Conger, J. A. (2004). Developing leadership capability: What's inside the black box? Academy of Management Executive, 18(3), 136-139.

9. Conley, L., Haley, F., McGregor, J., Prospero, M. A., Salter, C., \& Slacks, D. (2004, October). 2004 customers 1st. Fast Company, 87, 79.

10. Foster, B. A. (2000). Barriers to servant leadership: Perceived organizational elements that impede servant leader effectiveness. Dissertation Abstracts International, 61 (05), 1935. (UMI 9974230)

11. Greenleaf, R. K. (1972). The institute as servant. Indianapolis, IN: The Robert K. Greenleaf Center Press.

12. Greenleaf, R. K. (1977). Servant leadership: A journey into the nature of legitimate power and greatness. Mahwah, NJ: Paulist Press.

13. Greenleaf, R. K. (1996). On becoming a leader. San Francisco: Jossey Bass.

14. Greenleaf, R. K., Covey, S. R., \& Senge, P. M. (2002). Servant leadership: A journey into the nature of legitimate power \& greatness. Mahwah, NJ: Paulist Press.

15. Klenke, K. (2003). The "S" factor in leadership education, practice, and research. Journal of Education for Business, 79(1), 56-61.

16. Lynham, S., \& Chermack, T. (2006). Responsible leadership for performance: A theoretical model and hypotheses. Journal of Leadership \& Organizational Studies, 12(4), 73-88.

17. Northouse, P. G. (2004). Leadership: Theory and practice (3rd ed.). Thousand Oaks, CA: Sage.

18. Spears, L. C. (2002). Focus on leadership: Servant-leadership for the twenty-first century. New York: Wiley.

19. Spears, L. C. (2004). Practicing servant leadership. Leader to Leader, 34, 7-11.

20. Washington, R. R. (2007). Empirical relationships between theories of servant, transformational, and transactional leadership. Academy of Management Proceedings, 1-6. Retrieved December 13, 2007, from Business Source Complete database. 